\title{
Rethinking the sacred truths of global citizenship education: A theoretical exploration
}

\author{
Miri Yemini $^{1}$
}

Accepted: 10 October 2021

(C) UNESCO IBE 2021

\begin{abstract}
This article aims to unpack global citizenship education (GCE) as a concept, arguing that a certain moving forward is needed in the scholarship to allow true engagement of educators and thus students with the topic. It suggests that the contemporary research directions are entangled with strong trends of political correctness and a contrariness agenda, de facto nullifying school-based praxis. It also notes several assumptions in the GCE literature that may benefit from re-examination to critically engage with criticisms of GCE.
\end{abstract}

Keywords Global citizenship education $\cdot$ Schools $\cdot$ Students $\cdot$ Inclusiveness

Global citizenship education (GCE) is a concept that has gained popularity in the past decade as it was incorporated into the UN Sustainable Development Goals (SDGs) framework and subsequently into state curricula in many countries (Ghosn-Chelala, 2020). GCE is also echoed by the "global competencies" chapter in OECD's latest PISA release and resonates in the work of various non-governmental organisations (Goren, 2020). While widespread and generally accepted, GCE has been subject to severe criticism in academia and beyond, accused of being an empty signifier; a sign of Global North privilege and neo-colonialism; an inapplicable concept; decontextualised from the real-life teaching and learning opportunities; and, importantly, conceptualised differently at policy levels and in classroom realms. Global citizenship education aims to address values and knowledge that help learners to become informed and responsible citizens in the global world. Following Bosio and Torres's (2019, p. 747) call for GCE to be "based on values of mutuality and reciprocity", in this essay I seek to explore and question some of the basic assumptions and unwritten rules guiding much of the writing on GCE from the past decade.

Miri Yemini

miriye@tauex.tau.ac.il

1 School of Education, Tel Aviv University, 69978 Ramat Aviv, Tel Aviv, Israel 
To follow this route, I begin by exposing my positionality as a scholar enjoying certain privilege (a high-rank, tenured position at a leading research university, whiteness, and access in general to a high-quality standard of living). I also note my marginalised position as a woman, a non-native speaker of English, a Jew, and, importantly, an Israeli citizen working in academia, where Israelis are often immediately accused and sometimes banned, unilaterally blamed for the atrocities of the Israeli-Arab conflict. My marginality is further apparent within the Israeli society as I am an immigrant from the former Soviet Union, a non-native speaker of Hebrew, and from a working-class background, brought up in a family lacking social, financial, and linguistic capital. That is to say, my understanding of GCE is deeply embedded in my own ambiguous positionality and in my capability to reflect on and engage with various theories and practices of GCE.

Following the call by critical scholars (Pashby et al., 2020) to inform our scholarship through critical awareness of our own positionalities on personal and societal levels, I hereby question three central arguments dominating the academic discourse on GCE and then suggest some ideas that might not only resonate with these popular arguments but also, importantly, provide a solid alternative approach for future research.

The essay proceeds as follows. First, I present the common problematisations of GCE as these are mirrored in the contemporary academic scholarship. Then I discuss the alternatives to the common discourses, with the aim of materialising GCE as a self-aware praxis.

\section{Common reservations and critiques}

The critical discourse surrounding education for global citizenship raises a number of reproaches concerning the moral grounding of the term and its applicability. Recently, studies criticised the growing use of the concept by national curricula (Yemini et al., 2018a, b) and intergovernmental agencies (Auld \& Morris, 2019; Engel et al., 2019).

First, the prevailing assumption is that GCE is a privileged endeavour, particularly relevant to those under advantaged conditions who are able to be mobile across national borders; therefore, introducing the subject into curricula would create a gap that would increase the existent, inherent inequality in the system since some schools may be more willing and able to incorporate these topics than others (Goren \& Yemini, 2017; Howard et al., 2018; Torres \& Bosio, 2020). This link between mobility-and access to mobility, which Kaufmann et al., (2018) conceptualised as "motility"-and is often studied as a potential factor that increases gaps between mobile and moored individuals and societies. Moreover, forced mobility (as in the case of refugees and asylum-seekers or low-skilled migrants) might also reinforce these gaps due to limited access to schooling or low-level schooling available for these populations.

Nevertheless, theoretically speaking, I question this assumed strong link between mobility and GCE, especially nowadays when most of the world's schools moved to online or blended learning. At present, the most fundamental underlying notions of traditional schoolingincluding its timeline, age-based full-day activities, and other "educational truths"- are being reshaped by measures to mitigate the Covid-19 pandemic. While obviously urgent problems of access to computers and stable internet connectivity remain, which will harm the most vulnerable populations, free mobility as such, even for middle- and upper-class students, is no longer obvious. Thus, potentially, schools will be able to deliver new forms of GCE detached from physical mobility, and motility might be redefined by access and skills in virtual worlds 
rather than in the real world, where some are more limited than others by citizenships and passports, regulations and restrictions (Harpaz, 2019).

A second argument against GCE is that this is a broad and multidimensional topic whose relevance is distinct and specific for different populations; therefore, the ability to quantify and measure its use, as is a common practice with new topics entering the curriculum, is limited (Auld \& Morris, 2019). In other words, in order to be implemented in the curriculum, unification and universalisation of GCE programmes is required; yet such an act would undermine the fundamental understanding that education for global citizenship is inherently contextual and ever-changing. This criticism is part of a broader discourse propagated by leading comparative educators such as Bob Lingard (Baroutsis \& Lingard, 2017; Lewis et al., 2016; Lingard \& Lewis, 2017), Paul Morris, (2015), and many others against the OECD's attempt to shape education policy in nation-states based on large-scale assessment and international comparisons. While, in general, many studies confirmed the limited reliability of these international standardised examinations and their biased conclusions (e.g., Feniger \& Lefstein, 2014; Komatsu \& Rappleye, 2017), not often are any alternatives offered in this type of scholarship or in general. Moreover, curricular integration of GCE does not necessarily mean that its curricular materials must be assessed and compared or that GCE must be delivered using universal curricula and therefore global assessment.

A third argument deals with the gap between the theory and writing of policy-makers regarding education for global citizenship, on one hand, and the practice of what is being done in the classroom, on the other-and the inability of teachers and students alike to reconcile these contradictions and subtleties (Sant et al., 2018). Of course, this argument is valid for almost every topic in social sciences and the humanities, from history to political education to the arts. Teachers' agency is crucial when engagement with "difficult" issues is required in terms of dealing with controversies, questioning the existing hegemonies, and supporting student activism. Andreotti, (2016, p. 105) warns us against developing "ethnocentric, paternalistic, ahistorical and depoliticised practices based on a single onto-epistemic grammar that naturalises modern institutions, cognitive frames, structures of being and economic models". In that sense, however, GCE is no different from the broader discourses of civics, history, the arts, and literature. Therefore, the transformation of schooling that we aim for should be implemented for all topics, probably guided by bottom-up initiatives alongside agentic endeavours by educators, parents, students, and communities.

The fourth argument touches upon the foundations of GCE and argues that the concept is tainted with colonialism and the replication of power hierarchies between the Global North and the Global South. Therefore, the argument goes, the practice of GCE is corrupting and problematic, and requires re-engineering of existing power relations on the global stage (Pashby et al., 2020; Stein et al., 2019) to avoid reproduction of "material, discursive and political inequalities" (Andreotti, 2016, p. 102). In addition, scholars have offered multiple, conflicting definitions of GCE, and ample reviews have covered its different typologies. A multitude of divisions and subdivisions of the various types of GCE and of the core concept of global citizenship itself have been published in recent years, in the contexts of both schools and higher education. These discourses over definitions and typologies are being criticised increasingly in the academia and beyond (Pashby et al., 2020). 


\section{Possible alternatives for GCE}

After noting the major critiques raised against GCE implementation, I would like to move the discourse forward, suggesting possible alternatives to the conceptual understandings of GCE that may be impeding its practice. First, I argue against the sweeping abolition of conceptualisations and the tendency to question the legitimacy of writing that originates in the Global North. Reviews that call for more diverse voices in research and writing are of course just and legitimate, but in this area it sometimes seems that any knowledge produced in the West is immediately suspected of neocolonialism and the replication of hegemony. I claim that immediate refutation of any scholarship produced in the Global North is not helpful in the attempt to use GCE to fight structural and conceptual hegemonies. Broad generalisation of everything written by scholars and institutions in the North as racist and neocolonial is obviously biased and should be examined critically with the same scrutiny that is being applied in decolonising "Western knowledge". Andreotti (2016, p. 105) suggests that

[d] espite questions raised by critical scholars in the field, educational institutions across sectors, including supranational institutions like UNESCO, have adopted the rhetoric of GCE in ways that still reinforce ethnocentric, paternalistic, ahistorical and depoliticised practices based on a single onto-epistemic grammar that naturalises modern institutions, cognitive frames, structures of being and economic models. These practices tend to foreclose analyses of uneven power relations, the geopolitics and biopolitics of knowledge production and to conceal the complicity of modernity in the systemic reproduction of harm through historical and on-going forms of violence, exploitation, dispossession and destitution mobilised to protect specific interests.

Andreotti (2016, p. 108) further proposes to examine GCE practices following the HEADS UP model:

- Hegemony (justifying dominance and supporting domination);

- Ethnocentrism (projecting the views of one group as universal);

- Ahistoricism (forgetting historical legacies and complicities);

- Depoliticization (disregarding power inequalities and ideological roots of analyses and proposals);

- Self-congratulatory and self-serving attitude (oriented towards self-affirmation/CV building);

- Uncomplicated solutions (ignoring the complexity of epistemological, ontological, and metaphysical dominance); and

- Paternalism (seeking affirmation of superiority through the provision of help).

I add that we should take double caution when developing, evaluating, and implementing GCE: once in detecting and identifying biases within GCE stemming from the West/ rest historical power relations and again when criticising conceptions of GCE that originated in the West so as not to throw out the baby with the bath water, metaphorically speaking.

Second, I challenge us to reimagine the relationship of the literature in the field with the concept of neoliberalism. The discourse on neoliberalism in and of education is complex; indeed, the term has been overused, and its overuse has been criticised (Rowe et al., 
2019). However, there is a growing tendency for researchers to blame endogenous and exogenous privatisation processes on the commercialisation of education and on widening achievement gaps (Ball, 2009). Part of what leads to this tendency is the extensive involvement of external organisations (non-profit organisations, foundations, and commercial companies) in education processes (Yemini et al., 2018a, b). As a relatively new concept in formal schooling that is heavily supported by intergovernmental organisations such as UNESCO and the OECD, GCE is not shielded from such criticism. While local NGOs and global intergovernmental organisations are involved in GCE in many countries, we should inquire into the specific relations formed in each case to understand whose agency is being expressed and who is excluded from the process. In certain cases, teachers, parents, and even students are the ones forming NGOs that enter schools to foster more fulfilling relationships within the local communities, through GCE (Torres, 2017). Moreover, the critique against assessment, especially by large international organisations and in particular the OECD, tends to recycle content and meanings. As such, this line of criticism holds back the development of new voices that would present other, non-Orthodox, streams of thought. Ultimately, schools are not exclusively oriented towards emphasising global competencies as per the OECD (Auld \& Morris, 2019), as we showed regarding teachers of various sectors within Israeli society (Goren et al., 2019).

My third argument deals with the negation of the entrepreneurship and agency of those engaged in education through somewhat nostalgic accusations of neoliberalism in favour of what was in the "past". When examined in depth, we often find education in the "past" to have been even more divisive than it is at present in terms of geography, gender, ethnicity, and other contexts (Estellés \& Fischman, 2020; Francis et al., 2017). The perception of globalisation and hitherto privatisation as new modes of action that unquestionably disturb equal public schooling is not accurate historically; it is based on a past that never existed. Today more than ever, dedicated and agentic educators are willing to develop students' skills and personalities. Moreover, the arguments against GCE based on a claim that global solidarity must reoccur are usually strongly grounded in what Beck (2007) called methodological nationalism.

\section{Conclusion}

Now that I have listed and questioned some of the most visible and unquestionable critiques of GCE, I suggest several new directions for thinking about GCE and, specifically, its implementation in classrooms. These days, we are witnessing enormous transformations by many national education systems worldwide. The mind frame of "from crisis to opportunity" adopted by some intergovernmental organisations and national governments leaves room for bottom-up initiatives and teacher-led changes to penetrate school systems that are otherwise extremely resistant to change. The need for global action in light of the Covid-19 pandemic provides us with a chance to re-examine GCE and its criticisms and to design specific local and global solutions through which educators and communities will be able to engage with this concept without fear of sacred truths and biased discourses.

As mentioned above, my thinking on GCE is closely linked to my own positionality as scholar, parent, and migrant. While conducting empirical research, interviewing teachers and students about their perceptions of GCE, I became acutely aware of the deep dissonance surrounding the academic writing on the topic. Critical evaluations of all existing projects, conceptualisations, typologies, and assessments made me rethink my own positioning in the field and encouraged me to turn my critical lens back towards the critical 
scholarship itself. I hope that this essay will provide a fertile ground for rethinking and developing GCE further, as the world seems to desperately need a fresh perspective.

\section{References}

Andreotti, V. (2016). The educational challenges of imagining the world differently. Canadian Journal of Development Studies/revue Canadienne D'études Du Développement, 37(1), 101-112.

Auld, E., \& Morris, P. (2019). Science by streetlight and the OECD's measure of global competence: A new yardstick for internationalisation? Policy Futures in Education, 17(6), 677-698.

Ball, S. J. (2009). Privatising education, privatising education policy, privatising educational research: Network governance and the "competition state." Journal of Education Policy, 24(1), 83-99.

Baroutsis, A., \& Lingard, B. (2017). Counting and comparing school performance: An analysis of media coverage of PISA in Australia, 2000-2014. Journal of Education Policy, 32(4), 432-449.

Beck, U. (2007). The cosmopolitan condition: Why methodological nationalism fails. Theory, Culture \& Society, 24(7-8), 286-290.

Bosio, E., \& Torres, C. A. (2019). Global citizenship education: An educational theory of the common good? A conversation with Carlos Alberto Torres. Policy Futures in Education, 17(6), 745-760.

Engel, L. C., Rutkowski, D., \& Thompson, G. (2019). Toward an international measure of global competence? A critical look at the PISA 2018 framework. Globalisation, Societies and Education, 17(2), $117-131$.

Estellés, M., \& Fischman, G. E. (2020). Who needs global citizenship education? A review of the literature on teacher education. Journal of Teacher Education, 72(2), 1-20.

Feniger, Y., \& Lefstein, A. (2014). How not to reason with PISA data: An ironic investigation. Journal of Education Policy, 29(6), 845-855.

Francis, B., Mills, M., \& Lupton, R. (2017). Towards social justice in education: Contradictions and dilemmas. Journal of Education Policy, 32(4), 414-431.

Ghosn-Chelala, M. (2020). Global citizenship education in conflict-affected settings: Implications of teachers' views and contextual challenges for the Lebanese case. Teaching and Teacher Education, 93(4), $1-20$.

Goren, H. (2020). Students in service of the state: Uncoupling student trips abroad and global competence. International Journal of Educational Development, 77(C), 1-20.

Goren, H., Maxwell, C., \& Yemini, M. (2019). Israeli teachers make sense of global citizenship education in a divided society-religion, marginalisation and economic globalisation. Comparative Education, 55(2), 243-263.

Goren, H., \& Yemini, M. (2017). The global citizenship education gap: Teacher perceptions of the relationship between global citizenship education and students' socio-economic status. Teaching and Teacher Education, 67, 9-22.

Harpaz, Y. (2019). Citizenship 2.0: Dual nationality as a global asset. Princeton University Press.

Howard, A., Dickert, P., Owusu, G., \& Riley, D. (2018). In service of the Western world: Global citizenship education within a Ghanaian elite context. British Journal of Educational Studies, 66(4), 497-514.

Kaufmann, V., Dubois, Y., \& Ravalet, E. (2018). Measuring and typifying mobility using motility. Applied Mobilities, 3(2), 198-213.

Komatsu, H., \& Rappleye, J. (2017). A PISA paradox? An alternative theory of learning as a possible solution for variations in PISA scores. Comparative Education Review, 61(2), 269-297.

Lewis, S., Sellar, S., \& Lingard, B. (2016). PISA for schools: Topological rationality and new spaces of the OECD's global educational governance. Comparative Education Review, 60(1), 27-57.

Lingard, B., \& Lewis, S. (2017). Placing PISA and PISA for schools in two federalisms, Australia and the USA. Critical Studies in Education, 58(3), 266-279.

Morris, P. (2015). Comparative education, PISA, politics and educational reform: A cautionary note. Compare: A Journal of Comparative and International Education, 45(3), 470-474.

Pashby, K., da Costa, M., Stein, S., \& Andreotti, V. (2020). A meta-review of typologies of global citizenship education. Comparative Education, 56(2), 144-164.

Rowe, E., Lubienski, C., Skourdoumbis, A., Gerrard, J., \& Hursh, D. (2019). Templates, typologies and typifications: Neoliberalism as keyword. Discourse: Studies in the Cultural Politics of Education, 40(2), $150-161$.

Sant, E., Davies, I., Pashby, K., \& Shultz, L. (2018). Global citizenship education: A critical introduction to key concepts and debates. Bloomsbury. 
Stein, S., Andreotti, V. D. O., \& Suša, R. (2019). "Beyond 2015" within the modern/colonial global imaginary? Global development and higher education. Critical Studies in Education, 60(3), 281-301.

Torres, C. A. (2017). Theoretical and empirical foundations of critical global citizenship education (Vol. I). London: Routledge.

Torres, C. A., \& Bosio, E. (2020). Global citizenship education at the crossroads: Globalization, global commons, common good, and critical consciousness. Prospects, 48(3), 99-113.

Yemini, M., Cegla, A., \& Sagie, N. (2018a). A comparative case-study of school-LEA-NGO interactions across different socio-economic strata in Israel. Journal of Education Policy, 33(2), 243-261.

Yemini, M., Goren, H., \& Maxwell, C. (2018b). Global citizenship education in the era of mobility, conflict and globalisation. British Journal of Educational Studies, 66(4), 423-432.

Publisher's Note Springer Nature remains neutral with regard to jurisdictional claims in published maps and institutional affiliations.

Miri Yemini is an Associate Professor of comparative education at Tel Aviv University, with interests in internationalisation of education in schools and higher education, global citizenship education, and education in conflict-ridden societies. She has also developed a strong research contribution around the involvement of external actors in schools. In addition, Prof. Yemini is an active member of CIES, CESE, and BAICE, and she is a President Elect for the Israeli Comparative Education Society. Prof. Yemini has published extensively, among others in Educational Administration Quarterly, Educational Management Administration \& Leadership, Comparative Education Review, Teaching and Teachers Education, Compare, Discourse: Studies in the Cultural Politics of Education, Journal of Studies in International Education, Globalisation, Societies and Education, Urban Education, and Educational Review. 